\title{
Morphological assessment of Niger Kuri cattle using multivariate methods
}

\author{
M. Grema ${ }^{1,2}$, A. Traorée ${ }^{3, \#}$, M. Issa ${ }^{1}$, M. Hamani ${ }^{1}$, M. Abdou ${ }^{1}$, I. Fernández ${ }^{4}$, A. Soudré ${ }^{5}$, I. \\ Álvarez $^{4}$, M. Sanou ${ }^{3}$, H.H. Tamboura ${ }^{3}$, Y. Alhassane ${ }^{1} \&$ F. Goyache ${ }^{4, \#}$ \\ ${ }^{1}$ Université Abdou Moumouni de Niamey, Faculté des sciences et techniques BP 10960, Niamey, Niger \\ ${ }^{2}$ Université de Diffa, BP 78 Diffa, Niger \\ ${ }^{3}$ INERA, Laboratoire de Biologie et santé animals, 04 BP 8645 Ouagadougou 04, Burkina Faso \\ ${ }^{4}$ SERIDA-Deva, Camino de Rioseco 1225, E-33394 Deva-Gijón (Asturias), Spain \\ ${ }^{5}$ Université de Koudougou, BP 376 Koudougou, Burkina Faso
}

(Received 28 November 2016; Accepted 24 May 2017; First published online 7June 2017)

\begin{abstract}
Copyright resides with the authors in terms of the Creative Commons Attribution 4.0 South African License.
See: http://creativecommons.org/licenses/by/4.0/za

Condition of use: The user may copy, distribute, transmit and adapt the work, but must recognize the authors and the South African Journal of Animal Science.
\end{abstract}

\begin{abstract}
A total of 406 adult cows and 34 bulls belonging to the Niger Kuri cattle population were assessed for 16 body measurements and 11 qualitative traits to contribute to the characterization of this unique cattle breed. Body measurements included facial, horn, ear and rump lengths; facial, cranial, shoulder, pelvic and ischium widths; height at withers and at hips; muzzle circumference; heart girth; body and tail lengths; and thorax depth. Qualitative traits included cephalic profile, ear shape, muzzle pigmentation, eyelid pigmentation, hoof pigmentation, horn colour, dewlap size, backline profile, horn shape, spotting pattern, and coat colour pattern. Data were analysed jointly with 377 individuals from four other West African taurine cattle breeds (N'Dama, Lagunaire, Lobi and Somba) using multivariate statistical methods, including canonical and correspondence analyses. Among the breeds analysed, Kuri cattle had the highest mean values for all body measurements: height at withers and body length had mean values of $124.0 \pm 0.4$ and $146.8 \pm 1.0 \mathrm{~cm}$ in Kuri cows, respectively, and $126.0 \pm 2.2$ and $155.7 \pm 3.6 \mathrm{~cm}$, respectively, in Kuri bulls. Canonical analysis allowed the construction of contour plots to illustrate the high differentiation between Kuri cattle and the other breeds, regardless of the sex of the individuals. Further, the Mahalanobis distance matrices showed that pairs involving Kuri cattle had the higher differentiation of these populations. Correspondence analysis carried out on these 11 qualitative traits allowed the researchers to ascertain a clear differentiation between the Kuri and the other taurine cattle breeds. The N'Dama, Lagunaire, Lobi, and Somba breeds did not show clear differentiation at qualitative-type trait level with $75 \%$ confidence regions computed for these four breeds being highly intermingled. In the current data, Kuri cattle had the highest frequency in qualitative features, such as concave cephalic profile, dropped ears, non-pigmented muzzle and grey-coloured horns, which are absent in West African taurine and zebu cattle breeds, according to the literature. The current evidence would suggest that unique Kuri cattle type features may result from breeding decisions rather than from zebu admixture. This work confirms that at type trait level Kuri cattle is a unique population within the West African taurine cattle group. The implementation of genetic analyses aiming at ascertaining the degree of uniqueness of the breed is advised.
\end{abstract}

Keywords: Body measurements, Bos taurus, multivariate analyses, qualitative traits, West African cattle \#Corresponding authors: traore_pa@yahoo.fr; fgoyache@serida.org

\section{Introduction}

Kuri cattle are bred on the shores and islands of Lake Chad. Lake Chad is located at the east of the arid Sahel agri-ecological region, between $12^{\circ} 20^{\prime}$ and $14^{\circ} 20^{\prime} \mathrm{N}$ latitude and $13^{\circ}$ and $15^{\circ} 30^{\prime} \mathrm{E}$ longitude, and is bordered by Cameroon, Chad, Niger and Nigeria. Although West African zebu (Bos indicus) cattle are the overwhelming majority in the Sahel area, the overall shape of the breed, including the absence of a hump, has traditionally led to Kuri cattle being classified as a representative of African taurine (B. taurus) longhorn cattle (Bourzat et al., 1992). Unlike the main representative of African taurine longhorn cattle, namely the N'Dama breed, Kuri cattle are not small and are trypanosusceptible.

Kuri cattle represent a unique case of adaptation to a particular environment. The breed is unable to survive out of the environments of Lake Chad owing to heat intolerance. However, these cattle have noticeable resistance to parasites and tolerance of insect bites. These cattle are bred mainly by the 
Boudouma ethnic group in Niger and the local rural populations use them for dairy and beef production. A number of reports have highlighted that the Kuri breed is highly endangered. According to Bourzat et al. (1992) and Tawah et al. (1997), Kuri cattle are threatened by a number of factors, including the difficult political situation of the countries bordering Lake Chad, the shrinking of the lake owing to the increasing duration of the dry season and unsupervised human water extraction, and frequent breeding practices, leading to zebu $x$ Kuri crosses. Using blood groups, lactoproteins, and microsatellites, Souvenir Zafindrajaona et al. (1999) reported that Kuri cattle are closer to the West African zebu than to West African taurine cattle. Hanotte et al. (2002) reported that the breed had admixture proportions of zebu genes of 0.435. However, Souvenir Zafindrajaona et al. (1999) reported that Kuri cattle carried the B. taurus submetacentric $Y$ chromosome. Overall, the current evidence of the genetic background of Kuri cattle would suggest that implementation of conservation strategies for Kuri cattle would be highly advised (Tawah et al., 1997).

The first step in the characterization of local genetic resources constitutes knowledge of the variation of morphological traits (Traoré et al., 2008a; Traoré et al., 2008b). Kuri cattle have received a great deal of attention owing to their unique horns, which vary from long horns with $20-30 \mathrm{~cm}$ basal circumference to bulbous or conical horns with a large basal circumference, which can exceed $60 \mathrm{~cm}$, and the spectacular buoy-shaped horns, which are only 15-25 cm in length (Tawah et al., 1997). However, comprehensive morphological assessment has not been carried out. Recently, nine West African cattle breeds were jointly analysed for body measurements and qualitative-type traits using multifactorial analyses (Traoré et al., 2015; Traoré et al., 2016). Such analyses are appropriate for assessing variations within and between populations because all measured morphological variables are considered jointly.

The aim of the current research was to assess the variation in phenotypic traits in a representative sample of Kuri cattle using the methodology reported by Traoré et al. (2015; 2016). Morphological variation assessed at both quantitative measurement and qualitative trait level was compared with other four West African taurine cattle breeds, which were sampled in Burkina Faso, Mali and Benin.

\section{Materials and Methods}

A total of 406 adult cows (ages ranging from 4 to 16 years) and 34 bulls (from 4 to 8 years old) belonging to 63 breeders of the Niger Kuri (locally known as Boudouma) cattle population were assessed for 16 body measurements and 11 qualitative traits. Animals were selected according to two criteria: i) they were kept by Boudouma stakeholders; and ii) they displayed the long or bulbous horns that are characteristic of the breed (Tawah et al., 1997).

Assessment was carried out at the sites of Kindjayindi (37 breeders; 340 cows and 27 bulls) and Sayam (26 breeders; 66 cows and 7 bulls) in the Diffa region of Niger (Figure 1). Kindjayindi belongs to the

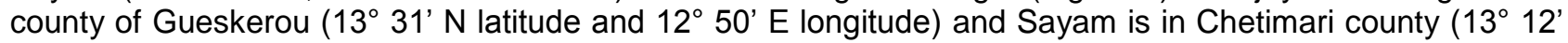
$\mathrm{N}$ latitude and $12^{\circ} 25^{\prime} \mathrm{E}$ longitude), both on the Niger shores of Lake Chad.

Body measurements and qualitative traits were assessed according to the guidelines of the Food and Agriculture Organization of the United Nations (FAO 2011) for phenotypic characterization of animal genetic resources. Assessment was carried out using the methods described in Traoré et al. $(2015 ; 2016)$. Body measurements obtained were facial length (from orbital fossa to upper lip), facial width (maximum width between facial tuberosities), cranial width (minimum width of the frontal bone), muzzle circumference, horn length (greater curvature), ear length, height at withers, heart girth, height at hips (tuber coxae), body length (from lateral tuberosity of the humerus to tuber ischi), thorax depth, tail length, shoulder width (between lateral tuberosities of the humerus), pelvic width (between tuber ischii), ischium width (between tuber ischii), and rump length (from tuber coxae to tuber ischii). Qualitative traits scored were cephalic profile, ears shape, muzzle pigmentation, eyelid pigmentation, hoof pigmentation, horn colour, dewlap size, backline profile, horn shape, spotting pattern, and coat colour pattern.

The ages of the individuals were approximated by examining dentition and through direct enquiries to owners. For statistical purposes, the ages of the individuals were grouped as follows: 4 years old (38 cows and 10 bulls); from 5 to 10 years (284 cows and 24 bulls); and older than 10 years ( 84 cows). Assessments were carried out in 2015 during the rainy season (August-September). Body measurements were carried out with the animals standing stationary on a flat floor, using a Lydthin stick, tape measure and Vernier callipers. Qualitative traits were scored with the same within-trait levels, codes and definitions used in Traoré et al. $(2015 ; 2016)$. Classifiers were trained to obtain consistent scoring with these reports. No animal ethical clearance was required for data collection. Body measurements and trait scores were obtained from technicians who visited farms with the permission of the owners. Animals were managed by the owners.

Data were jointly analysed with 377 individuals belonging to these West African taurine cattle breeds (Traoré et al., 2015; Traoré et al., 2016): N'Dama of Mali (18 cows and 9 bulls), Lagunaire of Benin (95 cows and 22 bulls), Lobi of Burkina Faso (74 cows and 24 bulls), and Somba of Benin (124 cows and 11 bulls). 


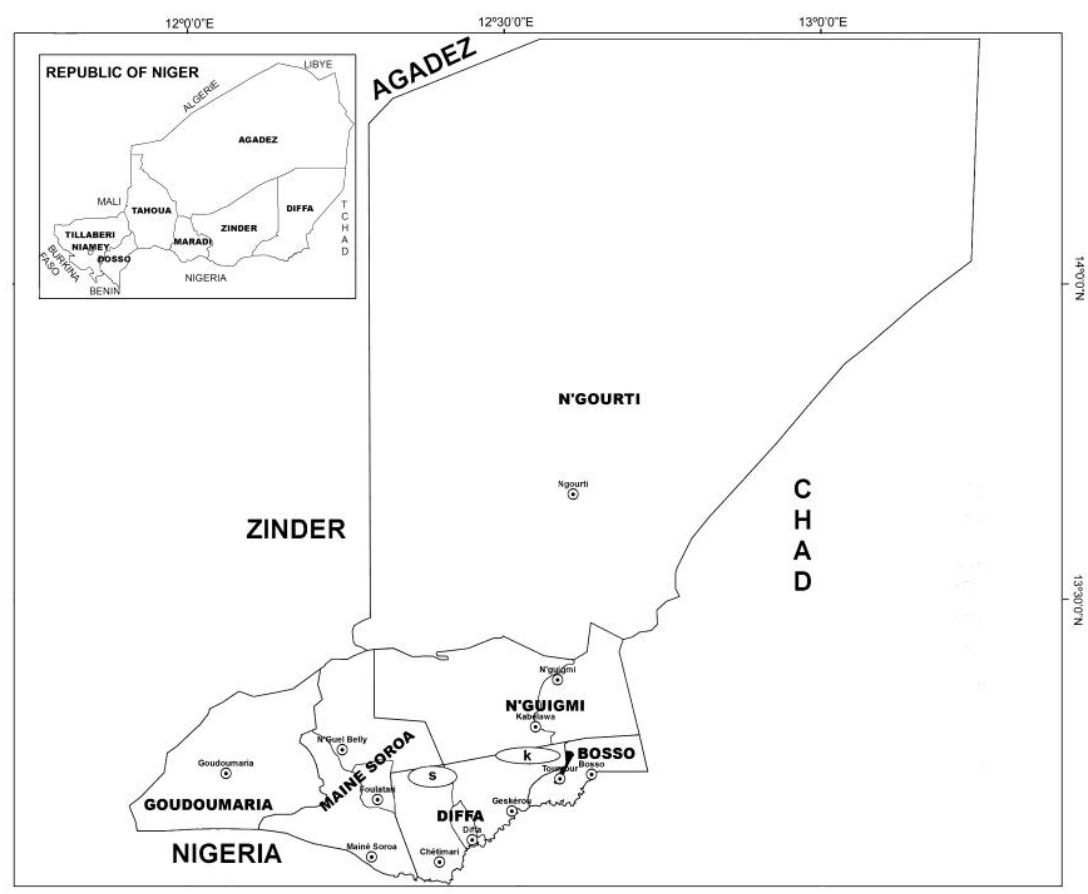

The sampling sites of Sayam (s) and Kinjandi (k), in Chetimari and Gueskerou counties, respectively, are identified.

Figure 1 County boundaries in Diffa region of Niger

Body traits were analysed separately for cows and bulls to avoid bias due to sexual dimorphism (see Traoré et al., 2016, including references) which is known to be particularly marked in the Kuri breed (Tawah et al., 1997). A simple model, including the effect of the breed (five levels) and the age of the individual (three levels for cows and two for bulls), was fitted using PROC GLM of SAS/STAT ${ }^{\mathrm{TM}}$ package (SAS Institute Inc., Cary, NC, 2016) to estimate least square means, and their corresponding standard errors, for each level of the breed effect. Additionally, Duncan's multiple range test was performed on the breed effect means. Body measurements were further analysed using the CANDISC procedure of SAS/STAT to perform canonical analyses: canonical functions, linear combinations of the quantitative variables that summarize between-breed variations, were derived and the between-breed Mahalanobis distance matrix was computed.

Frequencies of each level of these qualitative traits were computed using PROC FREQ of SAS/STAT ${ }^{T M}$. Statistical significance of the differences in these frequencies was assessed at breed level via chi-squared Mantel-Haenszel test. Relationships between qualitative traits were assessed via correspondence analysis using the PROC CORRESP of SAS/STAT ${ }^{\mathrm{TM}}$. Two canonical dimensions and their eigenvectors were computed to account for association between the levels of these traits. Following ParésCasanova \& Jordana (1999) each score of these qualitative traits was regarded arbitrarily as a polymorphism of the trait, and was used to compute the between-breeds Reynolds' distance matrix using the MolKin program (Gutiérrez et al., 2005). Statistical confidence on distance values was assessed via bootstrapping using 1000 replicates.

Eigenvectors computed for each individual via canonical and correspondence analyses were used to construct contour plots illustrating 75\% confidence region (per breed) of the relationships among individuals using the library ggplot2 of R (http://CRAN.R-project.org/).

\section{Results}

Least square means for the body measurements assessed by breed and sex are given in Table 1 . Data corresponding to the N'Dama, Lagunaire, Lobi and Somba breeds had previously been analysed in Traoré et al. $(2015 ; 2016)$. However, the datasets and models fitted for analyses were substantially different and least square estimates may vary. For both males and females, Kuri cattle had the highest values for all the analysed traits. For example, Kuri cows were $21.3 \mathrm{~cm}$ taller at height at withers than N'Dama cows and $41.7 \mathrm{~cm}$ taller than the dwarf Lagunaire breed. Furthermore, body length in Kuri cows was $36.9 \mathrm{~cm}$ and 42.4 $\mathrm{cm}$ longer than in the N'Dama and Lagunaire cows, respectively. 


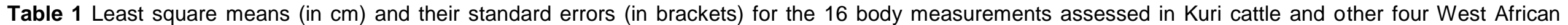
taurine breeds.

\begin{tabular}{|c|c|c|c|c|c|c|c|c|c|c|}
\hline & \multicolumn{5}{|c|}{ Cows } & \multicolumn{5}{|c|}{ Bulls } \\
\hline & Kuri & N'Dama & Lagunaire & Lobi & Somba & Kuri & N'Dama & Lagunaire & Lobi & Somba \\
\hline $\mathrm{N}$ & 406 & 18 & 95 & 74 & 124 & 34 & 9 & 22 & 24 & 11 \\
\hline Facial length & $50.9^{\mathrm{a}} \pm 0.2$ & $39.1^{\mathrm{b}, \mathrm{c}} \pm 0.8$ & $38.2^{c} \pm 0.3$ & $39.7^{b} \pm 0.4$ & $39.5^{b} \pm 0.3$ & $54.6^{\mathrm{a}} \pm 0.9$ & $39.2^{b} \pm 1.3$ & $36.3^{\mathrm{C}} \pm 1.0$ & $42.7^{b} \pm 0.9$ & $39.6^{b} \pm 1.3$ \\
\hline Facial width & $22.1^{\mathrm{a}} \pm 0.2$ & $14.8^{b} \pm 0.5$ & $18.7^{b} \pm 0.2$ & $19.1^{c} \pm 0.3$ & $16.9^{d} \pm 0.2$ & $26.5^{\mathrm{a}} \pm 1.1$ & $17.7^{b} \pm 1.5$ & $20.8^{b} \pm 1.2$ & $21.0^{b} \pm 1.1$ & $18.4^{b} \pm 1.5$ \\
\hline Cranial width & $22.4^{\mathrm{a}} \pm 0.3$ & $13.2^{d} \pm 1.0$ & $18.6^{b} \pm 0.5$ & $15.2^{c} \pm 0.5$ & $21.3^{\mathrm{a}} \pm 0.4^{\prime}$ & $28.9^{\mathrm{a}} \pm 1.2$ & $15.8^{d} \pm 1.6$ & $21.4^{\mathrm{b}, \mathrm{c}} \pm 1.3$ & $18.5^{\mathrm{c}, \mathrm{d}} \pm 1.2$ & $21.8^{\mathrm{b}} \pm 1.7$ \\
\hline Muzzle circumference & $40.5^{a} \pm 0.2$ & $39.5^{\mathrm{b}} \pm 0.7$ & $33.7^{d} \pm 0.3$ & $35.6^{c} \pm 0.3$ & $35.3^{c} \pm 0.3$ & $43.4^{\mathrm{a}} \pm 0.9$ & $39.6^{b} \pm 1.3$ & $33.0^{d} \pm 1.0$ & $37.9^{c} \pm 0.9$ & $35.4^{\mathrm{C}} \pm 1.3$ \\
\hline Horn length & $62.5^{\mathrm{a}} \pm 0.9$ & $28.6^{d} \pm 3.0$ & $9.4^{\mathrm{C}} \pm 1.4$ & $13.7^{\mathrm{C}} \pm 1.6$ & $13.6^{\mathrm{C}} \pm 1.2$ & $59.4^{a} \pm 2.5$ & $22.1^{\mathrm{b}} \pm 3.4$ & $11.1^{\mathrm{c}} \pm 2.7$ & $15.4^{\mathrm{c}} \pm 2.5$ & $13.5^{\mathrm{C}} \pm 3.5$ \\
\hline Ear length & $19.3^{\mathrm{a}} \pm 0.1$ & $14.0^{\mathrm{C}} \pm 0.4$ & $12.6^{d} \pm 0.2$ & $16.8^{\mathrm{b}} \pm 0.2$ & $12.3^{d} \pm 0.2$ & $19.1^{\mathrm{a}} \pm 0.4$ & $13.8^{\mathrm{C}} \pm 0.6$ & $12.1^{d} \pm 0.4$ & $16.8^{\mathrm{b}} \pm 0.4$ & $12.9^{c, d} \pm 0.6$ \\
\hline Height at Withers & $124.0^{a} \pm 0.4$ & $102.7^{b} \pm 1.4$ & $82.3^{\mathrm{e}} \pm 0.6$ & $90.6^{d} \pm 0.7$ & $94.9^{c} \pm 0.6$ & $126.0^{a} \pm 2.2$ & $101.8^{b} \pm 3.0$ & $82.5^{d} \pm 2.3$ & $95.8^{\mathrm{C}} \pm 2.1$ & $92.2^{c} \pm 3.0$ \\
\hline Heart girth & $152.9^{a} \pm 0.7$ & $132.1^{b} \pm 2.2$ & $115.8^{C} \pm 1.0$ & $129.1^{b} \pm 1.1$ & $127.5^{\mathrm{b}} \pm 0.9$ & $157.7^{a} \pm 3.5$ & $128^{b} \pm 4.9$ & $111^{\mathrm{c}} \pm 3.8$ & $136.0^{b} \pm 3.5$ & $122^{b} \pm 4.9$ \\
\hline Height at Hips & $131.6^{a} \pm 0.4$ & $105.8^{b} \pm 1.4$ & $84.2^{e} \pm 0.6$ & $93.2^{d} \pm 0.7$ & $99.0^{c} \pm 0.6$ & $135.3^{a} \pm 1.7$ & $105.3^{b} \pm 2.4$ & $82.7^{d} \pm 1.9$ & $99.1^{c} \pm 1.7$ & $98.6^{\mathrm{C}} \pm 2.4$ \\
\hline Body length & $146.8^{a} \pm 1.0$ & $109.9^{b} \pm 3.1$ & $104.4^{b} \pm 1.4$ & $109.1^{b} \pm 1.6$ & $108.2^{b} \pm 1.3$ & $155.7^{a} \pm 3.6$ & $108.8^{b} \pm 4.9$ & $99.4^{c} \pm 3.8$ & $121.1^{b} \pm 3.5$ & $109.7^{b} \pm 5.0$ \\
\hline Thorax depth & $69.2^{\mathrm{a}} \pm 0.4$ & $54.6^{b} \pm 1.2$ & $45.9^{d} \pm 0.6$ & $48.0^{c} \pm 0.6$ & $49.1^{c} \pm 0.5$ & $74.6^{\mathrm{a}} \pm 2.0$ & $57.2^{b} \pm 2.7$ & $44.7^{d} \pm 2.1$ & $52.5^{\mathrm{C}} \pm 2.0$ & $51.1^{\mathrm{C}} \pm 2.7$ \\
\hline Tail length & $23.7 \pm 0.3$ & $19.3^{\mathrm{C}} \pm 1.0$ & $18.2^{d} \pm 0.4$ & $26.2^{b} \pm 0.5$ & $17.3^{\mathrm{C}} \pm 0.4$ & $25.2^{\mathrm{a}} \pm 1.0$ & $22.7^{\mathrm{C}} \pm 1.4$ & $15.3^{d} \pm 1.1$ & $27.4^{b} \pm 1.0$ & $18.8^{\mathrm{C}} \pm 1.4$ \\
\hline Shoulder width & $131.5^{b} \pm 0.9$ & $66.7^{\mathrm{c}} \pm 2.8$ & $57.4^{\mathrm{c}, \mathrm{d}} \pm 1.3$ & $83.4^{\mathrm{a}} \pm 1.5$ & $65.4^{d} \pm 1.2$ & $139.7^{\mathrm{a}, \mathrm{b}} \pm 3.0$ & $61.8^{b} \pm 4.1$ & $52.2^{d} \pm 3.2$ & $87.4^{a} \pm 3.0$ & $62.7^{\mathrm{C}} \pm 4.1$ \\
\hline Pelvic width & $44.9^{\mathrm{a}} \pm 0.3$ & $29.1^{c} \pm 0.9$ & $29.8^{\mathrm{b}, \mathrm{c}} \pm 0.4$ & $30.9^{b} \pm 0.5$ & $29.2^{c} \pm 0.4$ & $45.7^{\mathrm{a}} \pm 1.1$ & $28.9^{b, c} \pm 1.6$ & $25.7^{d} \pm 1.2$ & $32.6^{b} \pm 1.1$ & $28.3^{\mathrm{C}} \pm 1.6$ \\
\hline Ischium width & $14.4^{\mathrm{a}} \pm 0.3$ & $12.3^{b} \pm 1.1$ & $11.6^{b} \pm 0.5$ & $11.5^{b} \pm 0.6$ & $12.1^{b} \pm 0.5$ & $10.2^{\mathrm{a}, \mathrm{b}} \pm 0.6$ & $10.8^{\mathrm{a}, \mathrm{b}} \pm 0.8$ & $9.7^{b} \pm 0.6$ & $11.7^{\mathrm{a}} \pm 0.6$ & $10.3^{a, b} \pm 0.8$ \\
\hline Rump length & $41.0^{a} \pm 0.2$ & $32.1^{\mathrm{C}} \pm 0.8$ & $33.9^{c} \pm 0.3$ & $32.0^{c} \pm 0.4$ & $34.1^{b} \pm 0.3$ & $39.2^{\mathrm{a}} \pm 1.0$ & $30.9^{b} \pm 1.4$ & $31.7^{b} \pm 1.1$ & $32.4^{b} \pm 1.0$ & $31.9^{b} \pm 1.4$ \\
\hline
\end{tabular}

Sample size $(\mathrm{N})$ is given

significantly different trait means between the breeds analysed at $P<0.05$.

Statistical analyses were carried out separately for cows and bulls. 
The canonical analysis identified two statistically significant $(P<0.001)$ canonical variables in both male and female datasets. Canonical dimensions accounted for $79.95 \%$ and $12.49 \%$ of the total variation, respectively, in the bull dataset and $84.89 \%$ and $9.75 \%$, respectively, in the cow dataset. The solutions provided by the canonical analysis at individual level were plotted on a two-dimensional space to illustrate the between-breed relationships for body measurements (Figure 2). Substantial differentiation among West African taurine breeds was found. The $75 \%$ confidence regions computed for N'Dama, Lagunaire, Lobi, and Somba breeds were only partially intermingled on the Y-axis, particularly in bulls (Figure 2B). For both males and females, on the $\mathrm{X}$-axis, Kuri cattle were highly differentiated from the other cattle breeds.

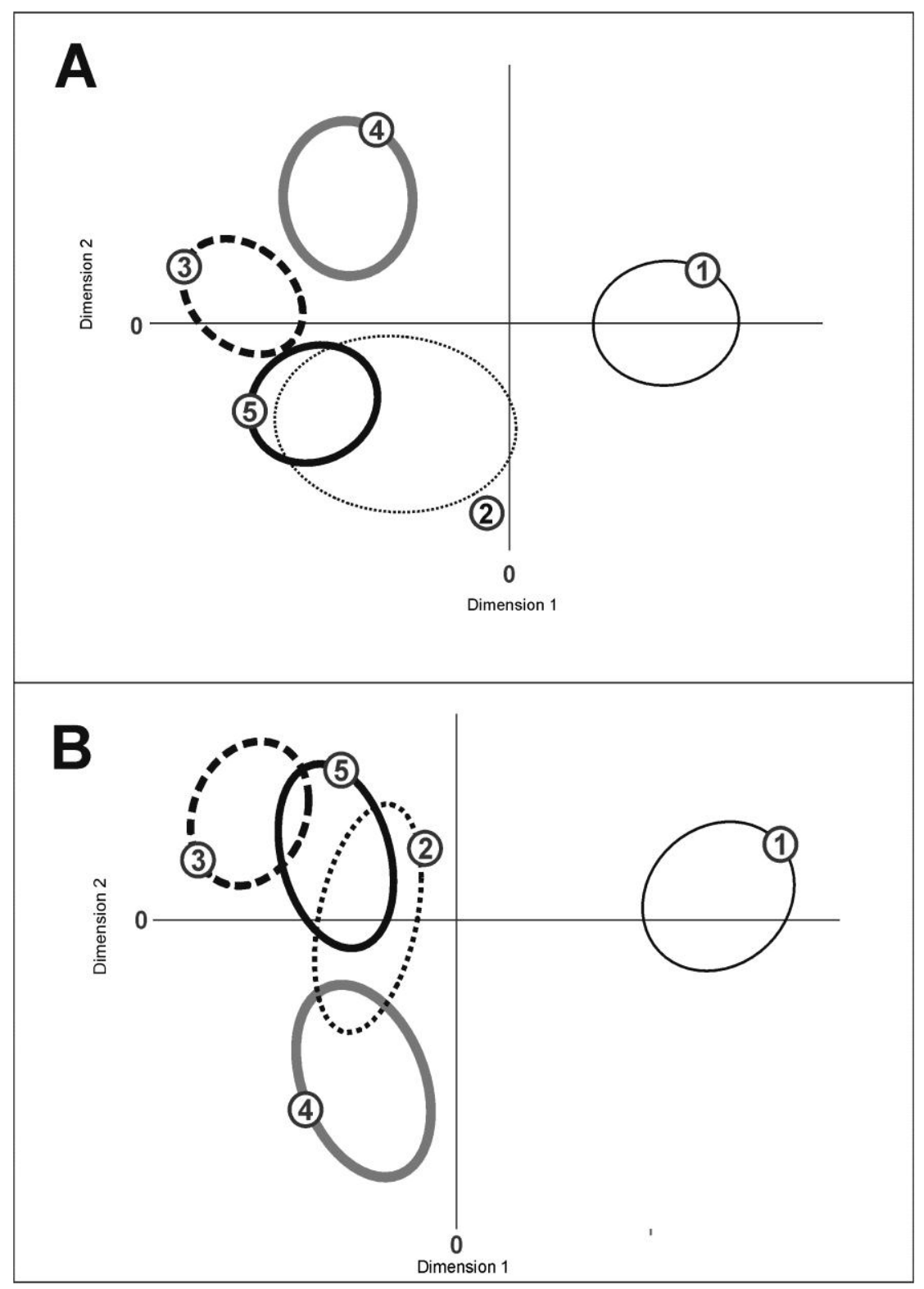

Contours show the $75 \%$ confidence region of the within-breed relationships among individuals. Canonical dimension 1 is on the $\mathrm{X}$-axis and canonical dimension 2 on the $\mathrm{Y}$-axis. Plot A corresponds to the female subset and Plot $\mathrm{B}$ to the bull subset. Numbers on contours mean the following: 1: Kuri; 2: N'Dama; 3: Lagunaire; 4: Lobi; and 5: Somba.

Figure 2 Contour plots summarising, per breed, the information provided by the 16 body traits analysed via canonical analyses 
The between-breeds Mahalanobis distance matrix is given in Table 2. All pair-wise distances were statistically significant $(P<0.001)$. The hypothesis that the breed means are equal in the populations analysed was also tested using Wilks' lambda. This parameter took a significant value $(P<0.0001)$ for both the bulls $(\lambda=0.00184481 ; F=19.68$; degrees of freedom $=64)$ and the cows $(\lambda=0.0067602 ; F=110.24$; degrees of freedom $=64$ ) datasets. Therefore, these differences were statistically different from zero. For both bulls and cows, the largest distances were found between Kuri cattle and the other breeds. In both sexes the higher differentiation was found for the Kuri-Lagunaire pair (149.3 for cows and 104.1 for bulls). In contrast, differentiation owing to body measurements among the N'Dama, Lagunaire, Lobi, and Somba breeds was substantially lower, ranging between 11.7 for the Somba-Lagunaire cow pairs and 54.7 for the N'Dama-Lagunaire bull pairs.

Table 2 Between-breed Mahalanobis distance matrices computed within sex using 16 body measurements

\begin{tabular}{lrrrrr}
\hline & Kuri & N'Dama & Lagunaire & Lobi & Somba \\
\hline Kuri & & 66.6 & 104.1 & 70.7 & 75 \\
N'Dama & 102.3 & & 54.7 & 46.6 & 21.7 \\
Lagunaire & 149.3 & 43.1 & & 23.8 & 16 \\
Lobi & 97.6 & 34.9 & 38.4 & & 31.4 \\
Somba & 100.3 & 18.4 & 11.7 & 24.6 &
\end{tabular}

The distance matrix computed on the cow dataset is below diagonal. The distance values corresponding to the bulls' dataset are above diagonal. All distance pairs are statistically significant for $P<0.0001$.

The frequency (in percentage) of each level of the 11 qualitative traits recorded for Kuri cows and bulls is given in Table 3. Data corresponding to the N'Dama, Lagunaire, Lobi and Somba breeds were previously analysed at within-sex level by Traoré et al. $(2015 ; 2016)$. Here, for convenience, results corresponding to these four breeds are presented with no sex separation, except for Kuri cattle. The within-sex chi-squared Mantel-Haenszel test showed that incidence of all the analysed traits varied significantly among cattle breeds for $P<0.001$. This was basically because the large differences that were found between the Kuri cattle and the other cattle breeds. Table 3 shows that the 'average' Kuri individuals had a concave cephalic profile, dropped ears and a non-pigmented muzzle. Further, Kuri cattle frequently show grey-coloured horns, well developed dewlaps, lyre-shaped horns and white coats with no spotting pattern. This general appearance departs substantially from that of the other West African taurine cattle breeds analysed (Table 3).

A correspondence analysis was carried out on the 11 qualitative traits. Two correspondence dimensions accounted for $64.92 \%$ and $23.00 \%$ of the total variation, respectively, in the bull dataset and $51.90 \%$ and $19.97 \%$, respectively, in the cow dataset. The solutions provided for each individual by the correspondence analysis were plotted in a two-dimensional space. Figure 3 shows that the $75 \%$ confidence region computed for the Kuri breed is clearly separated from those of the other four breeds at both cow and bull level. In turn, regardless of the sex, no clear differentiation could be assessed among the N'Dama, Lagunaire, Lobi, and Somba breeds using qualitative trait information. The $75 \%$ confidence regions computed for these four breeds were highly intermingled.

Between-breed Reynolds distance matrices were computed for each sex to quantify differentiation owing to qualitative type traits (Table 4). In general, regardless of sex, the pairs involving Kuri cattle had the higher distance values. However, the Kuri-Lobi pairs took values of $0.081 \pm 0.006$ for females and $0.320 \pm$ 0.040 for bulls, which were comparable with the distances assessed within sex among the N'Dama, Lagunaire, Lobi, and Somba breeds. 
Table 3 Frequencies (in percentage) of each level of the 11 qualitative traits assessed in Kuri cattle and other four West African taurine cattle breeds

\begin{tabular}{|c|c|c|c|c|c|c|c|c|}
\hline \multirow[b]{2}{*}{ Trait } & \multicolumn{2}{|r|}{ Class } & \multicolumn{2}{|c|}{ Kuri } & \multirow[b]{2}{*}{ N'Dama } & \multirow[b]{2}{*}{ Lagunaire } & \multirow[b]{2}{*}{ Lobi } & \multirow[b]{2}{*}{ Somba } \\
\hline & Code & Definition & Bulls & Cows & & & & \\
\hline $\mathrm{N}$ & & & 34 & 409 & 27 & 117 & 98 & 135 \\
\hline \multirow[t]{2}{*}{ Cephalic profile } & 1 & concave & 70.6 & 88.5 & & 3.7 & 0.9 & 0.5 \\
\hline & 3 & straight & 29.4 & 11.5 & 100.0 & 96.3 & 99.1 & 99.5 \\
\hline \multirow[t]{2}{*}{ Ear shape } & 1 & horizontal & & & 100.0 & 100.0 & 99.1 & 100.0 \\
\hline & 2 & drop & 100.0 & 100.0 & & & 0.9 & \\
\hline \multirow[t]{2}{*}{ Muzzle pigmentation } & 1 & pigmented & 17.7 & 12.0 & 70.4 & 98.5 & 95.4 & 95.5 \\
\hline & 2 & not pigmented & 82.4 & 88.0 & 29.6 & 1.5 & 4.6 & 4.5 \\
\hline \multirow[t]{2}{*}{ Eyelid pigmentation } & 1 & pigmented & 47.1 & 58.0 & 81.5 & 98.5 & 95.4 & 96.7 \\
\hline & 2 & not pigmented & 52.9 & 42.1 & 18.5 & 1.5 & 4.6 & 3.3 \\
\hline \multirow[t]{2}{*}{ Hoof pigmentation } & 1 & pigmented & 50.0 & 61.9 & 96.3 & 97.1 & 97.2 & 95.3 \\
\hline & 2 & not pigmented & 50.0 & 38.1 & 3.7 & 2.9 & 2.8 & 4.7 \\
\hline \multirow[t]{4}{*}{ Horn colour } & 1 & black & 5.9 & 4.2 & 7.4 & 12.5 & 64.9 & 27.0 \\
\hline & 2 & grey & 91.2 & 79 & 7.4 & 1.5 & 0.9 & 3.3 \\
\hline & 3 & brown & 2.9 & 16.8 & 85.2 & 66.7 & 33.3 & 18.2 \\
\hline & 4 & two coloured & & & 19.3 & 0.9 & 51.5 & \\
\hline \multirow[t]{3}{*}{ Dewlap size } & 1 & well developed & 35.3 & 2.7 & 11.1 & 0.7 & 0.9 & \\
\hline & 2 & poorly developed & 61.8 & 96.1 & 55.6 & 5.9 & 1.4 & 32.4 \\
\hline & 3 & small & 2.9 & 1.2 & 33.3 & 93.4 & 97.7 & 67.6 \\
\hline \multirow[t]{3}{*}{ Backline profile } & 1 & straight & 73.5 & 89.2 & 100.0 & 100.0 & 100.0 & 100.0 \\
\hline & 2 & concave & & 0.7 & & & & \\
\hline & 3 & convex & 26.5 & 10 & & & & \\
\hline \multirow[t]{6}{*}{ Horn shape } & 1 & cup & 17.7 & 38.2 & 7.4 & 73.5 & 61.6 & 46.9 \\
\hline & 2 & crescent & 26.5 & 34.7 & 55.6 & 13.3 & 9.1 & 41.9 \\
\hline & 3 & lyre & 52.9 & 19.1 & 14.8 & 3.0 & & \\
\hline & 4 & wheel & 2.9 & 3.2 & 3.7 & 0.7 & 10.8 & 4.5 \\
\hline & 5 & crown & & 4.0 & 4.0 & 8.8 & 17.1 & 6.7 \\
\hline & 7 & en arrière & & 0.7 & & & & \\
\hline \multirow[t]{3}{*}{ spotting pattern } & 1 & absence & 64.7 & 53.1 & 96.3 & 23.7 & 38.2 & 15.9 \\
\hline & 2 & pied & 14.7 & 24.9 & & 60.9 & 13.7 & \\
\hline & 3 & spotted & 20.6 & 22 & 3.7 & 15.5 & 48.2 & 84.1 \\
\hline \multirow[t]{13}{*}{ coat colour pattern } & 1 & black & & 0.5 & & 19.3 & 16.9 & 16.5 \\
\hline & 2 & black-pied & & & & 67.4 & 22.3 & 37.0 \\
\hline & 3 & white & 58.8 & 50.6 & 3.7 & 7.3 & & 0.5 \\
\hline & 4 & red & 5.9 & 13.2 & & 0.7 & 0.9 & 1.1 \\
\hline & 5 & red-pied & 2.9 & 0.7 & & 3.0 & 1.8 & 7.9 \\
\hline & 6 & roan & & & & 0.7 & 1.8 & 1.1 \\
\hline & 7 & fawn & 2.9 & 11.5 & 92.6 & 0.7 & 14.1 & 0.5 \\
\hline & 8 & diluted fawn & & 3.4 & 3.7 & & 5.1 & 12.8 \\
\hline & 9 & grey & & 3.4 & & & & \\
\hline & 10 & blond & 2.9 & 0.7 & & & & \\
\hline & 11 & fawn-blond & & 0.5 & & & 20 & 8.3 \\
\hline & 12 & dun-red & & 0.2 & & 0.7 & 16.3 & 5.6 \\
\hline & 13 & fawn-red & & 0.5 & & & 0.9 & 8.6 \\
\hline
\end{tabular}

Sample size $(\mathrm{N})$ is given.

Data are given per sex for Kuri cattle and for the two sexes for the other four cattle breeds.

Open cells mean that no records for a given level of a trait existed in a given breed. 


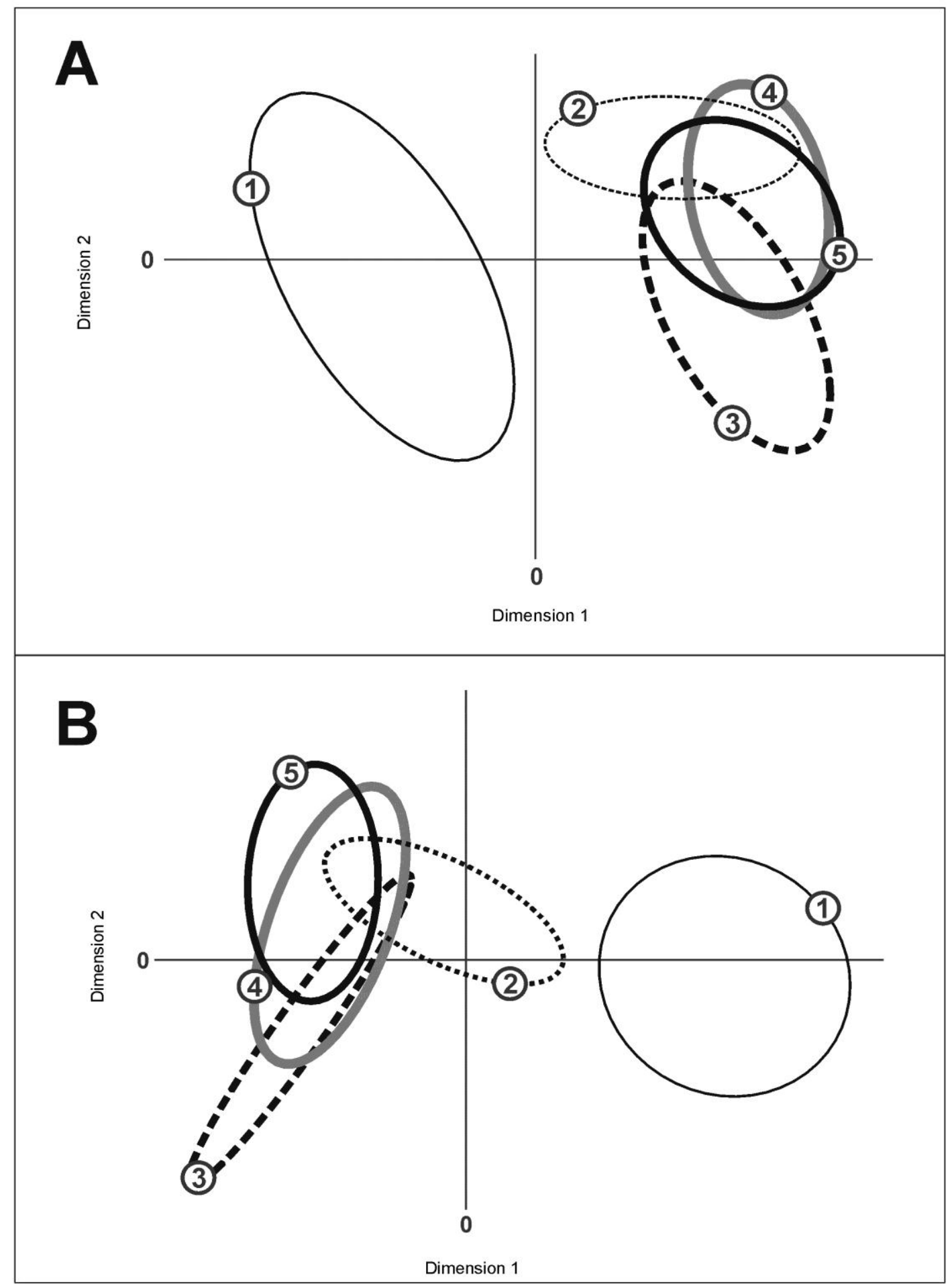

Contours show the $75 \%$ confidence region of the within-breed relationships among individuals. Correspondence dimension 1 is on the $\mathrm{X}$-axis and correspondence dimension 2 on the $\mathrm{Y}$-axis. Plot A) corresponds to the female subset and Plot B) corresponds to the male subset. Numbers on contours mean the following: 1: Kuri; 2: N'Dama; 3: Lagunaire; 4: Lobi; and 5: Somba.

Figure 3 Contour plots summarising, per breed, the information provided by the 11 qualitative traits analysed via correspondence analyses 
Table 4 Between-breed Reynolds distance matrices computed within sex using individual scores of 11 qualitative-type traits

\begin{tabular}{lccccc}
\hline & Kuri & N'Dama & Lagunaire & Lobi & Somba \\
\hline Kuri & & $0.650(0.073)$ & $0.545(0.048)$ & $0.320(0.040)$ & $0.465(0.048)$ \\
N'Dama & $0.289(0.012)$ & & $0.177(0.060)$ & $0.465(0.127)$ & $0.309(0.100)$ \\
Lagunaire & $0.252(0.009)$ & $0.111(0.018)$ & & $0.268(0.061)$ & $0.137(0.043)$ \\
Lobi & $0.081(0.006)$ & $0.196(0.023)$ & $0.189(0.025)$ & & $0.517(0.118)$ \\
Somba & $0.328(0.011)$ & $0.129(0.020)$ & $0.082(0.013)$ & $0.144(0.015)$ &
\end{tabular}

The distance matrix computed on the cow dataset is below diagonal. The distance values corresponding to the bull dataset are above diagonal. Standard deviations of the estimates of Reynolds distance pairs (in brackets) were computed via bootstrapping using 1000 replicates.

\section{Discussion}

In the past decade, reports that analysed morphological variation in East African cattle were more frequent than in West African cattle (Mwacharo et al., 2006; Ndumu et al., 2008; Yakubu et al., 2009). Recent reports in West African taurine and zebu cattle contributed to bridging this information gap (Traoré, et al., 2015; Traoré, et al., 2016). Current research confirms that Kuri cattle are a rarity in the framework of West African taurine cattle (Bourzat et al., 1992). Indeed, all individuals analysed here were humpless cattle. However, Kuri cattle differ from other West African taurine cattle in two significant aspects: Kuri are not small sized; and they are trypanosusceptible (Tawah et al., 1997). The current research is hoped to contribute to knowledge about that morphological differentiation. Clearly, Kuri cattle are larger than other West African taurine cattle breeds (see Table 1) and larger than West African zebu cattle, according the literature. For example, Kuri cattle had higher values for height at withers $(124.0 \pm 0.4 \mathrm{~cm}$ for cows and $126.0 \pm 2.2 \mathrm{~cm}$ for bulls) and body length $(146.8 \pm 1.0 \mathrm{~cm}$ for cows and $155.7 \pm 3.6 \mathrm{~cm}$ for bulls) than Nigerian White Fulani cattle (Yakubu et al., 2009) and Zebu Azawak of Burkina Faso (Traoré et al., 2015; Traoré, et al., 2016). In Nigerian White Fulani cattle height at withers and body length had mean values of $101.11 \pm 2.19$ and 152.29 $\pm 4.63 \mathrm{~cm}$ for bulls and $100.48 \pm 2.70$ and $154.34 \pm 7.52 \mathrm{~cm}$ for cows, respectively. Zebu Azawak of Burkina Faso had mean values of $119.3 \pm 3.7$ and $132.1 \pm 5.3 \mathrm{~cm}$, respectively, for bulls and $118.4 \pm 1.2$ and $127.3 \pm$ $1.9 \mathrm{~cm}$, respectively, for cows.

Previous reports that focused on Kuri cattle are scarce. Using 20 adult cows (10) and bulls (10), Tawah et al. (1997) (see Table 2 of that paper) reported mean values for 10 body measurements in Kuri cattle. Eight of these body traits were consistent with the current study's dataset. Tawah et al. (1997) characterized individuals that were more compact than those analysed here. The Kuri individuals sampled in their study were taller (height at withers of $151.3 \pm 6.38 \mathrm{~cm}$ for bulls and $138.1 \pm 5.42 \mathrm{~cm}$ for cows), shorter (body length of $122.3 \pm 7.75 \mathrm{~cm}$ for bulls and $116.4 \pm 8.96 \mathrm{~cm}$ for cows), and more 'rounded' (heart girth of $195.0 \pm 7.47 \mathrm{~cm}$ for bulls and $181.7 \pm 6.42 \mathrm{~cm}$ for cows). The definitions of body traits and the performances of technicians may not be fully consistent among zoometry works and large-type differences are likely to exist among local subpopulations of Kuri cattle across the shores and islands of Lake Chad. However, the main source of variation that explains differences between the current work and that of Tawah et al. (1997) is likely to be the small sample size available in that paper, and probably farmers' unexpected selection of the individuals to be measured according to their expectations of the 'quality' of the animals. The current results are completely representative only of the Niger subpopulation of the Kuri breed. However, the current morphological results were obtained from large numbers of individuals of both sexes sampled randomly and according to methodologies that had previously been applied in nine West African cattle breeds belonging to four West African countries (Traoré et al., 2015; Traoré, et al., 2016). Because of this background and because no differential selection on type traits is expected in different subpopulations of a basically unselected breed, the authors can suggest that the current results are representative of the whole breed.

At qualitative trait level, Kuri cattle showed high differentiation from the other West African taurine breeds analysed. In an analysis of nine cattle breeds, Traoré et al. $(2015 ; 2016)$ did not find patterns of variation on qualitative-type traits that allowed clear differentiation among cattle groups (taurine, zebu, or Sanga) or breeds. It is possible to argue that Kuri differentiation arises because the current work did not include zebu. The continuous unsupervised crossing of Kuri cattle with zebu individuals (Bourzat et al., 1992; 
Tawah et al., 1997) could have led to an increase in the frequency of qualitative features linked to zebu cattle. This could be supported by the relatively low distance assessed between the Kuri and the Lobi breeds using qualitative-type traits (Table 4). The Lobi population of Burkina Faso was recently reported to have significant proportions of West African zebu genes (0.293 \pm 0.086 ; Álvarez et al. 2014). However, the current data suggest that Kuri cattle show large frequency in certain features that are not frequent in zebu or in taurine West African cattle breeds (see the corresponding Tables 3 in Traoré et al., 2016; Traoré et al., 2016). For example, Kuri cattle have large frequencies of concave cephalic profile, dropped ears, nonpigmented muzzle or grey horns, while these qualitative characteristics are absent in the taurine and zebu breeds (Traoré et al., 2016; Traoré, et al., 2016) that were assessed in the past.

Desta et al. (2011) suggested that unlike European cattle, variations for qualitative traits in African cattle depend on the local preferences of stockkeepers. Traoré et al. $(2015 ; 2016)$ gave evidence that confirmed this suggestion. The Kuri breed has certain qualitative-type features in relatively higher frequency than other taurine and zebu cattle breeds, such as non pigmented eyelid and convex backline profile. This would suggest that the frequency of qualitative type traits in Kuri cattle is likely to result from breeding decisions rather than zebu introgression. Such decisions are probably linked to ancestral belief in the relationship between type traits and performance in a harsh environment, and may have contributed to keeping Kuri cattle as they are known until the present day.

The current work is the first step in the characterization of Kuri cattle, which are morphologically unique in the West African taurine cattle framework. Furthermore, these cattle represent a remarkable example of natural adaptation to a harsh environment (Tawah et al., 1997). However, the breed has not been included in most recent analyses on $\mathrm{Y}$ chromosome variation in African cattle (Pérez-Pardal et al., 2010) or studies aiming at ascertaining the genetic basis of trypanotolerance (Álvarez et al., 2016a; Álvarez et al., 2016b; Álvarez et al., 2016c). Further initiatives, with their basis in this project, would contribute to increase the knowledge on the genetic background of Kuri cattle.

\section{Conclusion}

Although there is controversy over the origin and classification of the Kuri breed as taurine or Sanga cattle, the current work does not provide evidence that allows the rejection of the inclusion of Kuri cattle in the West African taurine cattle group. In any case, at type trait level, Kuri is a unique population within this group. Further genetic analyses are advised to ascertain admixture proportions with zebu cattle and their possible relationship with type variation in the breed, the presence of unique genetic features characterizing West African taurine cattle and their susceptibility to trypanosomosis.

\section{Acknowledgements}

The authors are grateful for the financial support provided by West African Agricultural Productivity Programme (WAAPP/Niger). The authors are indebted to breeders involved in this study for their kind collaboration. This study made use of data generated under the CORAF/WECARD-World Bank no. 03/GRN/16. FG, IF and are supported by Grant FICYT GRUPIN14-113.

\section{Authors' Contributions}

$M G$ and $A T$ conceived the project; MG, MI, MH, MA, and YA planned and performed the sampling. AT, AS, IA, MS, HHT and FG contributed to data; AT, IA, IF and FG performed most statistical analyses; MG, AT, IF, and FG wrote the paper. All authors read, commented on and approved the final manuscript.

\section{Conflict of Interest Declaration}

The authors declare that there is no conflict of interest.

\section{References}

Álvarez, I., Pérez-Pardal, L., Traoré, A., Fernández, I. \& Goyache, F., 2016a. Lack of haplotype structuring for two candidate genes for trypanotolerance in cattle. J. Anim. Breed. Genet. 133, 105-114.

Álvarez, I., Pérez-Pardal, L., Traoré, A., Fernández, I.\& Goyache, F., 2016b. Lack of specific alleles for the bovine chemokine (C-X-C) receptor type 4 (CXCR4) gene in West African cattle questions its role as a candidate for trypanotolerance. Infect. Genet. Evol. 42, 30-33.

Álvarez, l., Pérez-Pardal, L., Traoré, A., Fernández, I. \& Goyache, F., 2016c. African cattle do not carry unique mutations on the exon 9 of the ARHGAP15 gene. Anim. Biotech. 27, 9-12.

Álvarez, I., Traoré, A., Fernández, I., Lecomte, T., Soudré, A., Kaboré, A., Tamboura, H.H. \& Goyache, F., 2014. Assessing introgression of Sahelian zebu genes into native Bos taurus breeds in Burkina Faso. Mol. Biol. Rep. 41, 3745-3754.

Bourzat, D., Idriss, A. \& Zeuh, V., 1992. La race Kuri: Une population bovine en danger d'absorption. AGRI 9, 13-21.

Desta, T.T., Ayalew, W. \& Hedge, B.P., 2011. Breed and trait preferences of Sheko cattle keepers in southern Ethiopia. Trop. Anim. Health Prod. 43, 851-856.

FAO, 2011. Guidelines to phenotypic characterization of animal genetic resources. FAO, Rome, Italy. 
Gutiérrez, J.P., Royo, L.J., Álvarez, I. \& Goyache, F., 2005. MolKin v2.0: a computer program for genetic analysis of populations using molecular co-ancestry information. J. Hered. 96, 718-721.

Hanotte, O., Bradley, D.G., Ochieng, J.W., Verjee, Y., Hill, E.W. \& Rege, J.E., 2002. African pastoralism: genetic imprints of origins and migrations. Science 296, 336-339.

Mwacharo, J.M., Okeyo, A.M., Kamande, G.K. \& Rege, J.E.O., 2006. The small East African shorthorn zebu cows in Kenya. I: Linear body measurements. Trop. Anim. Health Prod. 38, 65-74.

Ndumu, D.B., Baumung, R., Hanotte, O., Würzinger, M., Okeyo, M.A., Jianlin, H., Ibogo, H.K. \& Sölkner, J., 2008. Genetic and morphological characterization of the Ankole Longhorn cattle in the African Great Lakes region. Genet. Sel. Evol. 40, 467-490.

Parés-Casanova, P.M. \& Jordana, J., 1999. Relaciones genéticas entre razas ibéricas de caballos utilizando caracteres morfológicos (prototipos raciales). AGRI 26, 75-94 (in Spanish, English abstract).

Pérez-Pardal, L., Royo, L.J., Beja-Pereira, A., Curik, I., Traoré, A., Fernández, I., Sölkner, J., Alonso, J., Álvarez, I., Bozzi, R., Chen, S., Ponce de León, F.A. \& Goyache, F., 2010. Y-specific microsatellites reveal an African subfamily in taurine (Bos taurus) cattle. Anim. Genet. 41, 232-241.

Souvenir Zafindrajaona, P., Moazami-Goudarzi, K., Bourzat, D., Idriss, A., Zeuh, V., Laloë, D. \& Grosclaude, F., 1999. Etude du statut phylogénétique du bovin Kuri du lac Tchad à l'aide de marqueurs moléculaires. Rev. Elev. Med. Vet. Pays Trop.52, 155-162.

Tawah, C.L., Rege, J.E.O. \& Aboagye, G.S., 1997. A close look at a rare breed - the Kuri cattle of Lake Chad Basin: Origin, distribution, production and adaptive characteristics. S. Afr. J. Anim. Sci. 27, 31-40.

Traoré, A., Tamboura, H.H., Kabore, A., Royo, L.J., Fernández, I., Álvarez, I., Sangare, M., Bouchel, D., Poivey, J.P., Francois, D., Toguyeni, A., Sawadogo, L. \& Goyache, F., 2008a. Multivariate characterization of morphological traits in Burkina Faso sheep. Small Rumin. Res. 80, 62-67.

Traoré, A., Tamboura, H.H., Kabore, A., Royo, L.J., Fernández, I., Álvarez, I., Sangare, M., Bouchel, D., Poivey, J.P., Sawadogo, L. \& Goyache, F., 2008b. Multivariate analyses on morphological traits of goats in Burkina Faso. Arch. Anim. Breed. 51, 588-600.

Traoré, A., Koudandé, D.O., Fernández, I., Soudré, A., Álvarez, I., Diarra, S., Diarra, F., Kaboré, A., Sanou, M., Tamboura, H.H. \& Goyache, F., 2015. Geographical assessment of body measurements and qualitative type traits in West African cattle. Trop. Anim. Health Prod. 47, 1505-1513.

Traoré, A., Koudandé, D.O., Fernández, I., Soudré, A., Álvarez, I., Diarra, S., Diarra, F., Kaboré, A., Sanou, M., Tamboura, H.H. \& Goyache, F., 2016. Multivariate characterization of morphological traits in West African cattle sires. Arch. Anim. Breed. 59, 337-344.

Yakubu, A., Ogah, D.M., \& Idahor, K.O., 2009. Principal component analysis of the morphostructural indices of White Fulani cattle. Trak. J. Sci. 7, 67-73. 